ANETA BOEDYREW

ORCID 0000-0002-6121-0816

Uniwersytet Łódzki

PAULINA PAJĄK

ORCID 0000-0001-6911-1284

Uniwersytet Wrocławski

\title{
PERSPEKTYWY, MOŻLIWOŚCI I OGRANICZENIA BADAŃ ŁĄCZĄCYCH PSYCHOLOGIĘ I HISTORIĘ NAD EDUKACJĄ I WYCHOWANIEM DZIECI I MŁODZIEŻY U PROGU NOWOCZESNOŚCI ${ }^{1}$
}

\begin{abstract}
Bołdyrew Aneta, Pająk Paulina, Perspektywy, możliwości i ograniczenia badań łączacych psychologię i historię nad edukacją i wychowaniem dzieci i młodzieży u progu nowoczesności [Perspectives, Possibilities, and Limitations of Approaches Combining Psychology and History in Research on Education and Upbringing of Children and Youth on the Eve of Modernity]. Studia Edukacyjne nr 60, 2021, Poznań 2021, pp. 31-49. Adam Mickiewicz University Press. ISSN 1233-6688. DOI: 10.14746/se.2021.60.2

The past three decades have seen a heightened interest in integrating psychology and history in educational research. The aim of this article is to present interdisciplinary approaches combining psychological and historical perspectives in research on education and upbringing of children and youth on the eve of modernity. Using the examples of research projects that blend historical methods with Lifespan Developmental Psychology and Social Psychology, the authors analyse their possibilities and limitations. This article brings a new perspective to the studies on childhood and adolescence, with a special focus on people living in the Polish lands at the turn of the twentieth century.
\end{abstract}

Key words: history, psychology, education, childhood, interdisciplinarity

\section{Wprowadzenie}

Celem artykułu jest zaprezentowanie możliwości, perspektyw i ograniczeń zastosowania interdyscyplinarnych ujęć łączących psychologię i historię

${ }^{1}$ Publikacja finansowana, w ramach programu Ministra Nauki i Szkolnictwa Wyższego pod nazwą „Szlakami Polski Niepodległej”, w latach 2018-2023: nr projektu 01SPN 170020 18; kwota finansowania 751222 zł. 
w badaniach nad edukacją, wychowaniem i socjalizacją dzieci oraz młodzieży u progu epoki nowoczesnej, ze szczególnym uwzględnieniem realiów ziem polskich. W pierwszej części artykułu przedstawiono zarys ewolucji badań psychohistorycznych od drugiej połowy ubiegłego stulecia po dzień dzisiejszy, od psychoanalitycznych podejść określanych jako „psychohistoria” po interdyscyplinarne perspektywy łączące różne subdyscypliny historii i psychologii. Omówiono związane z tymi przemianami trudności definicyjne oraz głosy krytyczne wobec prób łączenia perspektyw historycznych i psychologicznych. W kolejnych częściach tekstu wskazano przykładowe obszary łączenia perspektyw historycznych i psychologicznych w badaniach nad edukacją, wychowaniem i socjalizacją dzieci oraz młodzieży, szerzej omawiając perspektywy psychologii rozwoju człowieka w biegu życia i psychologii społecznej. Zasygnalizowano możliwości i ograniczenia związane z próbą podjęcia takich badań $\mathrm{w}$ kontekście edukacji i wychowania młodego pokolenia u progu epoki nowoczesnej, w tym w odniesieniu do jednostek i grup zamieszkujących ziemie polskie na początku XX wieku.

\section{Od psychohistorii do interdyscyplinarnych badań łączących psychologię i historię}

Badania historyczne uwzględniające w swych interpretacjach perspektywę psychologiczną mają tradycję równie długą jak biografistyka, próbująca zarysować psychologiczne motywacje portretowanych osób. Ponieważ psychologia jest znacznie młodszą dyscypliną naukową, której początki sięgają drugiej połowy XIX wieku, podejścia psychologiczne uwzględniające kontekst historyczny przez długi czas ograniczały się do historii samej dyscypliny lub też sytuowały się na jej obrzeżach. Jednak w latach pięćdziesiątych i sześćdziesiątych popularnością zaczęła cieszyć się „psychohistoria”, włączająca podejścia (neo) psychoanalityczne i psychologii głębi do badań historycznych, traktowana wówczas zazwyczaj jako subdyscyplina psychologii, przede wszystkim z uwagi na sceptycyzm historyków wobec ujęć analitycznych.

Na gruncie polskiej nauki problemy ze zdefiniowaniem psychohistorii wielokrotnie sygnalizował Tomasz Pawelec, autor szeregu publikacji przybliżających badania psychohistoryczne². Jak pisał:

Pytanie "co to tak naprawdę jest psychohistoria?" nieustannie powracało. Wciąż "skrywała” się ona „za mgłą", niejednoznaczna, wielokonturowa, zaskakująca wciąż

${ }^{2}$ Zob. m.in. Psyche i Klio: historia w oczach psychohistoryków, oprac. T. Pawelec, Lublin 2002; T. Pawelec, Dzieje i nieświadomość: założenia teoretyczne i praktyka badawcza psychohistorii, Katowice 2004. 
nowym obliczem, a jednak niewątpliwie odciskająca wyraźny ślad na historiografii, filozofii historii czy wręcz całej XX-wiecznej humanistyce i myśli społecznej ${ }^{3}$.

Sam badacz uznaje psychohistorię zarówno za „paradygmat badań historycznych" i "dyscyplin[e] z pogranicza”, ",ruch naukowy (poznawczy) rozwijający się przede wszystkim na pograniczu akademickich studiów nad przeszłością (historiografii) oraz psychoanalizy stosowanej” oraz „społecz$\mathrm{n}$ [ą] praktyk[ę] badawcz[ą]" ${ }^{\prime}$. Wskazuje on także jej trzy wiodące obszary badawcze: psychobiografię, psychohistorię zbiorowości i studia nad dzieciństwem ${ }^{6}$. Choć Pawelec zauważa rosnącą popularność zastosowania innych niż psychologia dynamiczna subdyscyplin psychologii, to jednak traktuje je wyłącznie jako "segment psychohistorii" ${ }^{7}$.

Podobne wąskie rozumienie badań psychohistorycznych, utożsamiające je z zastosowaniem psychoanalizy i psychologii głębi oraz podtrzymujące tezę o prymacie podejść psychoanalitycznych, prezentuje Paul H. Elovitz, psychohistoryk, założyciel Forum Psychohistorycznego i redaktor naczelny kwartalnika "Clio's Psyche”. Jakkolwiek w opublikowanej w 2018 roku książce The Making of Psychohistory [Narodziny psychohistorii] definiuje on psychohistorię jako „amalgamat psychologii, historii oraz pokrewnych nauk społecznych. Koncentruje się ona na pytaniu o "przyczynę» historii, szczególnie zaś na różnicy pomiędzy zamierzeniami a rzeczywistym zachowaniem", to jednak wskazane przez niego obszary badawcze - „psychobiografia, dzieciństwo, dynamika grupy, mechanizmy obronne, reakcje na traumy, nieświadoma motywacja, sny oraz kreatywność" ${ }^{8}$ - odpowiadają tym tradycyjnie łączonym z psychologią dynamiczną.

W ostatnich trzydziestu latach można zaobserwować słabnące zainteresowanie zastosowaniami psychoanalizy do badań historycznych, a jednocześnie rosnącą popularność badań łączących perspektywę historyczną z różnymi subdyscyplinami psychologii. Jednym z tego powodów jest fakt, że prowadzona od około pięćdziesięciu lat systematyczna krytyka psychoanalizy skłania wielu naukowców do uznania jej za pseudonaukę ${ }^{9}$, choć zarazem

\footnotetext{
${ }^{3}$ T. Pawelec, Psychohistoria jako paradygmat badań historycznych. Konceptualizacja i program badawczy, Kultura i Historia, 2001, 1, s. 50.

${ }^{4}$ Tamże, s. 51.

${ }^{5}$ T. Pawelec, Dzieje i nieświadomość, s. 40-41.

${ }^{6}$ T. Pawelec, Psychohistoria jako paradygmat badań historycznych, s. 59; tenże, Dzieje i nieświadomość, s. 32-36.

7 T. Pawelec, Psychohistoria jako paradygmat badań historycznych, s. 59.

${ }_{8}^{8}$ P.H. Elovitz, The Making of Psychohistory: Origins, Controversies, and Pioneering Contributors, New York 2018, s. 2.

9 Zob. m.in. K. Popper, Science: Conjectures and Refutations, [w:] Philosophy of Science and the Occult, red. P. Grim, Albany 1990, s. 104-110; H.J. Eysenck, Zmierzch i upadek imperium Freuda, przekł. A. Jarczyk, Kraków 2002; F. Cioffi, Freud i pseudonauka, przekł. R. Stachowski, Kraków 2010.
} 
koncepcje (neo)psychoanalityczne są nadal wykorzystywane $\mathrm{w}$ analizach literaturo- czy kulturoznawczych. Wydaje się zatem, że to psychoanalityczna psychohistoria jest obecnie "segmentem" badań psychologiczno-historycznych; jej definicja systematycznie się poszerza, zaś sam termin „psychohistoria" (z uwagi na psychodynamiczne konotacje tego pojęcia) jest zastępowany takimi opisowymi terminami, jak interdyscyplinarne badania łączące psychologię i historię.

Jak przekonuje badacz psychobiografii William McKinley Runyan, już od lat siedemdziesiątych XX wieku wielu naukowców definiowało psychohistorię jako "zastosowanie dowolnej formy psychologii w badaniach historycznych" ${ }^{\prime 10}$. Przykładem takiego szerszego rozumienia terminu jest definicja Charlesa B. Stroziera, historyka i psychoanalityka, który z "psychohistorią" utożsamia

badania historyczne prowadzone z psychologicznego punktu widzenia. Pozostaje ona historią, ale usystematyzowaną psychologicznie przez pytania badawcze, które sobie stawia. Jednak odpowiedzi na te pytania powstają w historycznych ramach, a zatem stosując kryteria metodologii historycznej i podporządkowując się jej rygorom. To interdyscyplina - sam środek pomostu pomiędzy dwoma podejściami badawczymi (...). Łączy ona psychologiczne poszukiwania tego, co uniwersalne $z$ historyczną świadomością tego, co unikalne (...). Nie jestem zwolennikiem poglądu, że istnieją jakieś prawa historyczne, ale z pewnością można dostrzec pewne prawidłowości. Jednym z najważniejszych zadań historyków jest odkrycie i opisanie tych prawidłowości ${ }^{11}$.

W definicji tej widoczny jest nacisk na nieutożsamianie psychohistorii z psychoanalizą, a także przekonanie o komplementarnym charakterze obu dyscyplin.

Z uwagi na współczesną popularność interdyscyplinarnych perspektyw łączących subdyscypliny historii i psychologii, pojawiały się próby ich systematyzacji. Na przykład, McKinley Runyan postulował podział na psychohistorię („wykorzystanie psychologii do interpretacji historycznych"), historię $\mathrm{z}$ treścią psychologiczną (",odniesienia do zjawisk psychologicznych w relacjach historycznych”) oraz historyczną psychologię (,,badania tego, co transhistorycznie uniwersalne lub unikalne w zjawiskach psychologicznych) ${ }^{12}-$ systematyka ta jednak nie przyjęła się. W opublikowanej w 2014 roku książce

${ }^{10}$ W. McKinley Runyan, From the Study of Lives and Psychohistory to Historicizing Psychology: A Conceptual Journey, Annual of Psychoanalysis, 2003, XXXI: Psychoanalysis and History, s. 119132.

${ }^{11}$ Ch.B. Strozier, Interview, [w:] The Best of the Journal "Clio's Psyche" (1994-2005), red. P.H. Elovitz, Psychohistory Forum, Franklin Lakes 2013, s. 4-6.

${ }^{12}$ W. McKinley Runyan, Reconceptualizing the Relationships between History and Psychology, [w:] Psychology and Historical Interpretation, red. W. McKinley Runyan, New York 1988, s. 247248. 
Psychology and History: Interdisciplinary Explorations [Psychologia i historia: badania interdyscyplinarne], Cristian Tileagă i Jovan Byford zaprezentowali teoretyczne podstawy oraz sposoby zastosowania $\mathrm{w}$ badaniach interdyscyplinarnego dialogu pomiędzy historią i psychologią. Wyróżnili trzy podstawowe formy podejść łączących psychologię i historię: fuzja (ang. merger), transfer (ang. transfer) oraz przekład (ang. translation) ${ }^{13}$. Choć naukowcy nie wyjaśniają, w jaki sposób rozumieją pojęcie fuzji, podają jednak jej wyrazisty przykład: psychohistorię ( $w$ wąskim rozumieniu tego terminu). Za Peterem Loewenbergiem uznają oni, że dla psychohistoryków psychoanaliza stanowi „narzędzie do odkrywania ukrytych motywów i popędów (...) zarówno w odniesieniu do jednostek, jak i zbiorowości"14.

Natomiast, badania, w których zachodzi interdyscyplinarny transfer opierają się na zastosowaniu „konkretnych ustaleń, idei, czy pojęć jednej dyscypliny” do prób wyjaśnienia „motywacji czy zachowania ludzi” ${ }^{15}$. Naukowcy stosują zatem wyspecjalizowaną wiedzę jednej dyscypliny do poszukiwania odpowiedzi na pytanie badawcze w ramach innego podejścia. Jako przykład przywołano tu badania Christophera Browninga nad policjantami, którzy dopuścili się masowych mordów, w tym tak zwanej zbrodni w Józefowie, ludobójstwa około 1500 Żydów, przede wszystkim dzieci, kobiet i osób starszych $^{16}$. Historyk szukając przyczyn tych zbrodni, odwołał się do ustaleń psychologa społecznego Stanleya Milgrama i jego słynnych eksperymentów nad posłuszeństwem wobec autorytetu ${ }^{17}$.

Tileagă i Byford wskazali „przekład” jako najrzadziej występującą formę połączenia psychologicznych i historycznych perspektyw. Naukowcy dokonują „transformacji i re-interpretacji” ${ }^{18}$ pojęć oraz terminów jednej dyscypliny na język drugiej. Przykładem takiego podejścia jest subdyscyplina „historia emocji", która badając dzieje emocji posługuje się siatką pojęciową (neuro) psychologii, a zarazem sytuuje je w określonych kontekstach społecznych, politycznych, czy ekonomicznych ${ }^{19}$.

Podsumowując, Tileagă i Byford przyczyn trudności w łączeniu psychologii oraz historii upatrują w ich odmiennych podejściach do źródeł danych

${ }^{13}$ C. Tileagă, J. Byford, Introduction: psychology and history - themes, debates, overlaps and borrowings, [w:] Psychology and History: Interdisciplinary Explorations, red. C. Tileagă, J. Byford, New York 2014, s. 5-9.

${ }^{14}$ Tamże, s. 6.

15 Tamże.

${ }^{16}$ Zob. także Ch.R. Browning, Zwykli ludzie: 101. Policyjny Batalion Rezerwy i „ostateczne rozwiąanie" w Polsce, przekł. P. Budkiewicz, Warszawa 2000.

17 Ostatnio na temat badań Milgrama pisał M. Dymkowski, O źródłach Holokaustu w świetle badań nad destrukcyjnym postuszeństwem, HISTORYKA. Studia Metodologiczne, 2017, 47, s. 137161.

${ }^{18}$ C. Tileagă, J. Byford, Introduction: psychology and history, s. 7.

19 Zob. np. J. Plamper, The History of Emotions, Oxford 2017. 
i metodach ich interpretacji. We współczesnej psychologii - czy to społecznej, rozwojowej, czy klinicznej - wysoko cenione są podejścia „oparte na dowodach" (ang. evidence-based). Założenia takich teorii czy koncepcji psychologicznych muszą być potwierdzone przez rzetelne i replikowalne badania naukowe $^{20}$. Takie eksperymenty prowadzą do powstania kompletnych zbiorów danych, interpretowanych za pomocą metod statystycznych. Tymczasem, historycy z oczywistych względów najczęściej dysponują niepełnymi źródłami, zaś ocena odmiennych interpretacji źródeł dokonuje się przede wszystkim poprzez naukową debatę.

\section{Łączenie perspektyw historycznych i psychologicznych w badaniach nad wychowaniem i edukacją dzieci oraz młodzieży}

Szczególnie istotne miejsce $\mathrm{w}$ badaniach psychohistorycznych zajmują studia nad dzieciństwem i adolescencją. W przypadku studiów psychobiograficznych analiza przebiegu procesu dorastania była "obowiązkowym” obszarem dociekań autorów, zazwyczaj odwołujących się do koncepcji i ujęć psychoanalitycznych. Prowadziło to do wyjaśniania zachowań oraz motywacji dorosłych jako rezultatu doświadczeń i przeżyć z okresu dzieciństwa. Dzieciństwo traktowano jako zapowiedź antycypowanej dorosłości. Analizowano je nie tyle $\mathrm{w}$ jego wymiarze autotelicznym, co raczej jako proces dorastania "nie-dorosłych" czy „przed-dorosłych" - etap na drodze do osiągnięcia samodzielności, przygotowujący do dojrzałości i dorosłości. Wychowanie, socjalizację, edukację odczytywano głównie jako drogi transmisji kultury społeczności dorosłych, wiedzy, wartości i postaw wpajanych dzieciom.

Wyodrębnienie badań nad historią dzieciństwa jako niezależnego, samodzielnego obszaru studiów, integrujących perspektywy nauk o przeszłości oraz różne subdyscypliny psychologii, wiązało się z dążeniem do poznania sposobów doświadczania i przeżywania dzieciństwa w różnych epokach historycznych, z zastosowaniem wiedzy dostarczanej przez XX-wieczne teorie psychologiczne oraz wykorzystaniem inspiracji socjologicznych i antropologicznych $^{21}$. Można też dostrzec nurt prac o charakterze psychohistoryczno-

${ }^{20}$ Nieudane próby replikacji wielu badań doprowadziły zresztą do tzw. kryzysu replikacyjnego. W 2015 roku na łamach pisma „Science” zespół naukowców przedstawił wyniki prób replikacji badań, opublikowanych w cenionych czasopismach psychologicznych. Okazało się, że podobne wyniki uzyskano tylko w 39 na 100 prób replikacji. Open Science Collaboration [B. Nosek i in.], Estimating the reproducibility of psychological science, Science, 2015, 349, s. 1-8.

${ }^{21}$ Zob. np. A. Waloszek, Amerykańska historiografia poświęcona dzieciom i dzieciństwu w Stanach Zjednoczonych od czasów kolonialnych do wielkiego kryzysu ekonomicznego, Kwartalnik Historyczny, 1993, 2, s. 55-75. 
-antropologicznych, które niekiedy w większym stopniu odwoływały się do ustaleń historii społecznej, historii rodziny, historii życia codziennego oraz antropologii kulturowej niż psychologii. Jedna z najważniejszych - i budzących największe kontrowersje - koncepcji historii dzieciństwa została sformułowana przez amerykańskiego badacza Lloyda deMause'a ${ }^{22}$, twórcę tak zwanej "psychogennej teorii historii" ${ }^{23}$. Polemizując w wielu kwestiach z prekursorem badań nad historią dzieciństwa Philippem Ariès ${ }^{24}$, deMause zgadzał się z francuskim uczonym, że dzieciństwo będąc kategorią społeczną, stanowi zmienny w czasie ingredient procesu historycznego.

Ewolucji relacji między rodzicami a dzieckiem deMause przyglądał się z pozycji zaangażowanego obserwatora - terapeuty, realizującego misję społeczną, mającego na celu ujawnienie intencjonalnych i nieświadomych zaniedbań, przemocy, wykorzystywania dzieci - występujących w tym bardziej nasilonej skali, im bardziej odległą przeszłość poddajemy badaniu. Wyznaczając sześć podstawowych modeli rodzicielstwa (1. rodzicielstwo "dzieciobójcze" do ok. IV w. n.e.; 2. rodzicielstwo "porzucające”" do XIII w.; 3. rodzicielstwo ambiwalentne $\mathrm{w}$ XIV-XVII $\mathrm{w}$.; 4. rodzicielstwo natrętne $\mathrm{w}$ XVIII w.; 5. rodzicielstwo „socjalizujące” w XIX i pierwszej połowie XX w.; 6. rodzicielstwo "pomocne" rozwijające się współcześnie), uczynił z nich narzędzie periodyzacji dziejów, uznając, że wszelkie ważne zmiany historyczno-kulturowe są paralelne do kolejnych etapów ewolucji w pozycji w rodzinie i społeczeństwie jego małoletnich członków. Tekstom deMause'a stawiano wiele zarzutów: między innymi naiwną wiarę w linearny postęp, pochopne generalizacje, upraszczanie relacji rodzinnych i społecznych, pomijanie kontekstu społecznego, ekonomicznego i kulturowego, bagatelizowanie tych aspektów badanych zjawisk, które nie wpisywały się w przyjęte apriorycznie założenia, niereprezentatywność wykorzystanych źródeł, spekulacyjny charakter rozważań, eseistyczne ujęcie problemu ${ }^{25}$. Rozpatrując koncepcję deMause'a w perspektywie postkolonialnej, można zarzucić jej także stronniczość i skoncentrowanie na kulturze anglosaskiej, traktowanie zachodnich norm i ideałów wychowawczych jako uniwersalnych, brak dostatecznej wrażliwości na specyfikę innych kultur.

Mimo sceptycyzmu uczonych wobec tezy deMause'a o determinującym wpływie modelu doświadczania dzieciństwa kolejnych generacji na

${ }^{22}$ L. de Mause, Evolution of Childhood, [w:] The History of Childhood, red. L. de Mause, Northvale - London 1995.

${ }^{23}$ W. Kurth, Die psychogene Theorie von Lloyd deMause - Plädoyer für eine konstruktive Weiterentwicklung, Jahrbuch für Psychohistorische Forschung, 2009, 10, s. 201-243.

${ }^{24}$ Ph. Ariès, Historia dzieciństwa. Dziecko i rodzina w dawnych czasach, przekł. M. Ochab, Gdańsk 1995.

${ }^{25}$ W. Kurth, Wechselseitige Bezüge von Bindungstheorie und psychohistorischer Forschung, Jahrbuch für Psychohistorische Forschung, 2001, 2, s. 278; T. Pawelec, Dzieje i nieświadomość, s. 182. 
bieg historii oraz krytyki jego jednostronnej koncepcji, pomijającej pozytywne aspekty życia dzieci w przeszłości, miała ona istotny wpływ na rozwój badań nad (psycho)historią dzieciństwa. Wśród licznych opracowań część kontynuowała podejście deMause'a, koncentrując się na dramatycznych aspektach dzieciństwa. W tym nurcie utrzymywały się na przykład prace niemieckiej badaczki, wykładowczyni na Uniwersytecie we Frankfurcie nad Menem i członkini kolegium redakcyjnego "Journal of Psychohistory" Aurel Ende, która pisała, że prowadząc badania nad historią dzieciństwa, nie była w stanie „znieść więcej szczegółów na temat absolutnie żałosnego życia dzieci w przeszłości" ${ }^{26}$. Wielu autorów prac z dziedziny historii dzieciństwa, powstałych $\mathrm{w}$ paradygmacie psychohistorycznym, wyznaczało nowe pola analiz, poszukiwało nowych perspektyw interpretacyjnych i wyjaśniających, odchodząc od ujęcia "psychohistorycznego" na rzecz podejścia opartego na profilu poznawczym, wykorzystującym ustalenia i aparat pojęciowy różnych subdyscyplin psychologii.

Wydaje się, że przyszłość historii dzieciństwa i adolescencji uwzględniającej kontekst psychologiczny również należy do nurtu interdyscyplinarnych badań, łączących w różnym stopniu perspektywy psychologiczne i historyczne. Podjęcie takich analiz może prowadzić do wyznaczenia wielu nowych, interesujących obszarów związanych z edukacją, wychowaniem i socjalizacją dzieci oraz młodzieży, umożliwi także nowatorskie badania zagadnień, które wcześniej były przedmiotem zainteresowania historyków, stosujących tradycyjne narzędzia i metody. W obrębie współczesnej psychologii problematyka edukacji, wychowania i socjalizacji młodego pokolenia jest szczególnie eksplorowana przez jej dwie subdyscypliny: psychologię rozwoju człowieka w biegu życia (psychologię rozwojową) oraz psychologię społeczną. Wydaje się, że najbardziej rzetelne badania łączące psychologię i historię próbują odpowiedzieć na precyzyjnie zdefiniowane pytanie badawcze, dotyczące jednostki lub niewielkiej grupy w ściśle określonym kontekście historycznym. Natomiast, próby zastosowania teorii psychologicznych do wyjaśniania zjawisk psychologicznych na poziomie zbiorowości wydają się na obecnym etapie wiedzy mniej przekonujące i uprawnione.

\section{Wybrane możliwości \\ zastosowania psychologii rozwojowej i psychologii społecznej w kontekstach historycznych}

Jedną z najbardziej obiecujących perspektyw w interdyscyplinarnych badaniach nad edukacją, wychowaniem i socjalizacją dzieci oraz młodzieży wydaje się połączenie perspektywy historycznej i psychologii rozwojowej.

${ }^{26}$ A. Ende, Dzieciństwo psychohistoryka oraz historia dzieciństwa, [w:] Psyche i Klio, s. 195. 
Dotyczy to zwłaszcza długofalowych badań nad zmianami w zakresie opieki społecznej i edukacji, uwzględniających dokonania psychologii rozwoju człowieka w biegu życia. Kilkanaście krytycznych analiz takich badań zawiera opublikowana w 2005 roku książka Developmental Psychology and Social Change: Research, History and Policy [Psychologia rozwojowa i zmiana społeczna: badania, historia i polityka], pod redakcją psychologów Davida B. Pillemera i Sheldona H. White'a. Naukowcy zwracają uwagę, że badania nad opieką społeczną mogą pomóc w zapewnieniu skutecznego systemowego wsparcia dla dzieci i ich rodzin ${ }^{27}$. Jak wyjaśniają oni we wstępie, celem publikacji było

przyczynienie się do powstania lepszej i bardziej wyczerpującej «opowieści» o rozwoju człowieka w jak najszerszym kontekście historycznym, kulturowym i politycznym ${ }^{28}$.

Spośród kilkunastu rozdziałów prezentujących zastosowania tego interdyscyplinarnego podejścia, trzy modele wydają się najbardziej obiecujące i możliwe do aplikacji w polskich kontekstach historycznych początków XX wieku. Należą do nich propozycja Michelle Leichtman i Qi Wanga socjohistorycznej perspektywy w badaniach nad rozwojem pamięci autobiograficznej ${ }^{29}$; komparatystyczne analizy społecznych konsekwencji wprowadzenia obowiązku szkolnego, które przeprowadziły Barbara Rogoff, Maricela Correa-Ch'avez i Marta Navichoc Cotuc ${ }^{30}$; oraz przegląd badań nad skutkami reform opieki społecznej i programów przeciwdziałania biedzie autorstwa Alethy C. Huston ${ }^{31}$.

Po pierwsze, czynniki zidentyfikowane $\mathrm{w}$ badaniach Leichtman i Wanga mogą być pomocne $w$ analizie pamiętników i dzienników zawierających zapisy wspomnień związanych z wychowaniem, edukacją (formalną i nieformalną), oraz socjalizacją dzieci i młodzieży. Badacze przeanalizowali szereg okoliczności z bliskiego i dalszego środowiska potencjalnie wpływających na treści, które jednostka zapamiętuje oraz style wyrażania wspomnień ${ }^{32}$. Zdaniem Leichtman i Wanga, najsilniej na pamięć autobiograficzną oddziałują klimat polityczny, polityka rządu w konkretnych kwestiach oraz przemiany historyczne ${ }^{33}$.

${ }^{27}$ D.B. Pillemer, S.H. White, Introduction: What Kind of Science is Developmental Psychology?, [w:] Developmental Psychology and Social Change: Research, History and Policy, red. D.B. Pillemer, S.H. White, New York 2005, s. 5.

${ }^{28}$ Tamże, s. 20.

29 M.D. Leichtman, Q. Wang, A Socio-historical Perspective on Autobiographical Memory Development, [w:] Tamże, s. 34-58.

${ }^{30}$ B. Rogoff, M. Correa-Ch'avez, M. Navichoc Cotuc, A Cultural/Historical View of Schooling in Human Development, [w:] Tamże, s. 225-263.

${ }^{31}$ A.C. Huston, The Effects of Welfare Reform and Poverty Policies on Children and Families, [w:] Tamże, s. 83-103.

${ }^{32}$ M.D. Leichtman, Q. Wang, A Socio-historical Perspective, s. 34-48.

${ }_{33}$ Warto przy tym zauważyć, że naukowcy porównywali wspomnienia autobiograficzne chińskich jedynaków i osób posiadających rodzeństwo w kontekście polityki jednego dziecka w Chinach, a zatem dobierając skrajny przykład ingerencji polityki w życie rodzinne jednostki. 
Drugim studium, którego metodologiczne przesłanki zasługują na zastosowanie $\mathrm{w}$ badaniach psychologiczno-historycznych, jest próba oceny konsekwencji wprowadzenia obowiązku szkolnego, którą podjęły Rogoff, Correa-Ch'avez i Navichoc Cotuc. Autorki przekonują, że współczesna „masowa, obowiązkowa i powszechna edukacja sama w sobie jest krótkotrwałym eksperymentem", którego cele i formy podlegają nieustannym przemianom ${ }^{34}$, co ma poniekąd uzasadnić dość ryzykowną próbę zestawienia odmiennych kontekstów socjohistorycznych. Badaczki w pracach historycznych poszukiwały zjawisk łączonych z rozwojem masowego szkolnictwa wśród rodzin pochodzenia europejskiego w Stanach Zjednoczonych, od uzyskania niepodległości, po czasy współczesne. Następnie, stosując obserwację i wywiady, sprawdziły oddziaływanie wyłonionych czynników na trzy pokolenia Majów z Gwatemali ${ }^{35}$. Wśród kluczowych konsekwencji obowiązku szkolnego dla dzieci i ich rodzin, Rogoff, Correa-Ch'avez i Navichoc Cotuc wymieniają odseparowanie dzieci od dorosłych, a zarazem wzmocnienie kontaktów $\mathrm{z}$ rówieśnikami oraz rodzeństwem $\mathrm{w}$ zbliżonym wieku, zmniejszenie liczby członków rodziny, oraz mniejszy udział dzieci w opiece nad młodszym rodzeństwem, podkreślając przy tym, że do tych zmian przyczynia się też szereg innych niż edukacja czynników ${ }^{36}$.

Trzecim interesującym połączeniem perspektyw historycznych i psychologicznych jest przegląd badań zaprezentowany przez Alethę Huston, która zajmuje się problematyką wpływu biedy na rozwój i dobrostan dziecka. Prezentuje ona dotychczasowe ustalenia dotyczące wpływu polityki społecznej oraz pracy na dzieci i rodziny, podsumowując najważniejsze ustalenia badań longitudinalnych (uzyskanych za pomocą porównań podłużnych) i eksperymentalnych prowadzonych w Stanach ${ }^{37}$. Zestawienie to rzuca światło zarówno na to, że społeczno-rozwojowe badania mogą kształtować strategie polityki społecznej, jak i na użyteczność danych uzyskanych podczas wdrażania programów opieki społecznej dla psychologii rozwojowej. Huston kierowała badaniami eksperymentalnymi w ramach projektu "New Hope” [Nowa Nadzieja], sprawdzając skuteczność programu przeciwdziałania ubóstwu, który miał na celu poprawę sytuacji ekonomicznej rodziny i uzyskanie przez jej dorosłych członków zatrudnienia ${ }^{38}$. W badaniach nad dobrostanem dzieci zespół Huston zastosował model, oparty na ustaleniach Vonnie McLoyd i Marthy Zaslow. Uwzględniał on takie aspekty, jak wpływ na sytuację rodzica/

${ }^{34}$ B. Rogoff, M. Correa-Ch'avez, M. Navichoc Cotuc, A Cultural/Historical View of Schooling, s. 257.

35 Tamże, s. 225.

36 Tamże, s. 256.

37 A.C. Huston, The Effects of Welfare Reform, s. 84.

${ }_{38}$ Tamże, s. 89-93. 
rodziców (w dziedzinie zatrudnienia, dochodów, psychicznego dobrostanu), procesy pośredniczące (instytucje opieki nad dzieckiem i aktywność dziecka, środowisko rodzinne i wychowanie), oraz korzyści dla dzieci i młodzieży (w zakresie edukacji i poziomu aspiracji, poczucia sprawczości i dobrostanu, zachowań społecznych oraz zdrowia) ${ }^{39}$.

Drugą ważną propozycję metodologiczną w badaniach edukacji, wychowania i socjalizacji dzieci oraz młodzieży stanowią podejścia łączące historię społeczną z psychologią społeczną. Wykorzystanie ustaleń psychologów na temat wzajemnych stosunków człowieka $\mathrm{z}$ otaczającym go światem, relacji z innymi osobami, grupami, instytucjami, wpływu kontekstu społecznego na sposób myślenia, emocje i zachowania jednostki pozwala podjąć wiele problemów funkcjonowania w konkretnych realiach historycznych dzieci i adolescentów. Bardzo interesujące są perspektywy badań nad wychowaniem i socjalizacją z wykorzystaniem ustaleń dotyczących wpływu społecznego, grup mniejszościowych oraz uprzedzeń. Jednym z przejawów wpływu społecznego jest skłonność ludzi do ulegania osobom postrzeganym jako autorytety, potwierdzona w eksperymentach Milgrama i wykorzystana w omówionych wcześniej badaniach Browninga do wyjaśnienia zachowania sprawców ludobójstwa. W latach sześćdziesiątych XX wieku Milgram ${ }^{40}$ wykazał, że większość ludzi jest gotowa podporządkować się presji autorytetu, nawet jeśli mogą w ten sposób wyrządzić krzywdę innemu człowiekowi ${ }^{41}$.

Przypomnienie w niniejszym tekście słynnych eksperymentów Milgrama jest nieprzypadkowe, bowiem $\mathrm{w}$ ich prowadzeniu wykorzystano kontekst edukacyjny - relację nauczyciel-uczeń. Osobie badanej przypadała w nim rola „nauczyciela”, który miał pomóc drugiemu uczestnikowi (a w rzeczywistości badaczowi) w nauce par słów, karząc go za popełniane błędy porażeniem prądem elektrycznym o sile rosnącej wraz z czasem trwania badania ${ }^{42}$. Niektórzy naukowcy, w tym Dariusz Doliński, kierujący polską wersją milgramowskiego eksperymentu, łączą doświadczenia edukacyjne i wychowawcze z podatnością na uleganie autorytetom ${ }^{43}$. Przypuszczenia te można by pró-

39 Tamże, s. 102-103.

40 S. Milgram, Behavioral Study of Obedience, Journal of Abnormal and Social Psychology, 1963,67, s. $371-378$.

41 Jedną z motywacji badań Milgrama była próba zrozumienia ludobójstwa w okresie II wojny światowej. Podobne tło historyczne odnajdziemy w opisach wielu badań i teorii rozwijanych w latach powojennych.

42 Okazało się, że pod słowną presją ze strony eksperymentatora-naukowca, większość „nauczycieli” (ok. 60-70\%) było gotowych porazić „uczniów” śmiertelną dawką prądu (450 woltów).

43 D. Doliński i in., Would You Deliver an Electric Shock in 2015? Obedience in the Experimental Paradigm Developed by Stanley Milgram in the 50 Years Following the Original Studies, Social Psychological and Personality Science, 2018, 8, s. 927-933. 
bować sprawdzić, badając kształtowanie roli autorytetów i posłuszeństwa w edukacji na początku XX wieku.

Z uwagi na głębokie podziały społeczne, wielokulturowy i wieloetniczny charakter społeczeństwa zamieszkującego ziemie polskie na początku XX wieku, szczególnie cenne wydaje się także uwzględnienie perspektywy społecznej psychologii uprzedzeń i stygmatyzacji. Opublikowana u progu XXI wieku książka Społeczna psychologia piętna (wydanie polskie 2008 r.), pod redakcją Todda F. Heathertona, Roberta E. Klecka, Michelle R. Hebl oraz Jaya G. Hulla, ukazuje problematykę stygmatyzacji wieloaspektowo, uwzględniając zarówno osoby stygmatyzujące i poddawane stygmatyzacji, procesy ich społecznych interakcji oraz strategie ich poprawy. Koncepcje szczególnie interesujące w kontekstach edukacji dzieci i młodzieży dotyczą ideologii usprawiedliwiających stygmatyzację osoby ${ }^{44}$ czy grupy oraz strategie radzenia sobie z piętnem podejmowane przez osoby doświadczające dyskryminacji i wykluczenia ${ }^{45}$. Interesujące perspektywy w tym zakresie związane są $\mathrm{z}$ badaniami porównawczymi postaw (w tym ideologii usprawiedliwiających piętnowanie) w szkolnictwie i instytucjach opiekuńczo-wychowawczych, przejawami ekskluzji i inkluzji wobec jednostek, grup i środowisk defaworyzowanych. Z kolei analiza dokumentów autobiograficznych, dotyczących doświadczeń edukacyjnych osób z grup mniejszościowych, mogłaby ujawnić stosowane przez nie strategie radzenia sobie z piętnem.

\section{Edukacja i socjalizacja młodego pokolenia u progu nowoczesności a perspektywy badań historyczno-psychologicznych}

Interesujące perspektywy badawcze dotyczą wychowania, kształcenia oraz socjalizacji dzieci i młodzieży $w$ dobie intensywnych przemian modernizacyjnych, determinowanych przez procesy urbanizacji, industrializacji, reformy rolne, zmiany społeczne, demograficzne, polityczne, prawno-ustrojowe i kulturalne. Mimo niejednoznaczności istoty owej modernizacji oraz rozbieżności co do momentu rozpoczęcia i przebiegu procesów unowocześniania, przyspieszenia głębokich przemian cywilizacyjnych, faktem były przemiany tradycyjnego ładu społecznego, opisywane w kategoriach przejścia od społeczeństwa tradycyjnego do nowoczesnego ${ }^{46}$. W krajach Europy

${ }^{44}$ Ch.S. Crandall, Ideologia i potoczne teorie piętna: usprawiedliwianie piętnowanie, [w:] Spoteczna psychologia piętna, red. T.F. Heatherton, R.E. Kleck, M.R. Hebl, J.G. Hull, Warszawa 2008, s. 126-146.

${ }^{45}$ C.R. Miller, B. Major, Radzenie sobie z piętnem i uprzedzeniem, [w:] Tamże, s. 225-250.

46 P. Sztompka, Socjologia zmian społecznych, przekł. J. Konieczny, Kraków 2005, s. 82. 
Zachodniej i USA przeobrażenia te rozpoczęły się u schyłku XVIII wieku, w Europie Środkowo-Wschodniej - około połowy XIX wieku ${ }^{47}$. W Królestwie Polskim krystalizację nowoczesności i modernizmu przyniósł pozytywizm, który był także czasem ostatecznej realizacji projektu oświeceniowego ${ }^{48}$. Definicje nowoczesności wyróżniają różne jej przejawy, a współczesne koncepcje znacznie bardziej niuansują pojmowanie modernizacji niż konceptualizacje z pierwszej połowy XX wieku. Do implikacji nowoczesności zalicza się ciągłe dążenie do reformy i zastępowanie przebrzmiałych, uznanych za zużyte wzorów, norm i wartości nowym ładem ${ }^{49}$. Poszukiwanie nowego porządku cechowało stałe przeobrażanie imaginarium społecznego oraz dążenie do wyznaczenia własnych kryteriów i odrębnych wzorów pochodzących z tej właśnie, nie z innych epok, co - jak pisał Jürgen Habermas - prowadziło do „ugruntowania nowoczesności w samej sobie"50.

W wielu ujęciach nowoczesności podkreśla się jej oświeceniowe podwaliny, wyrażające się w rosnącej racjonalności ludzkich postaw i zachowań, emancypację jednostki i uniezależnianie się od tradycyjnych ograniczeń. Często eksponuje się rudymentarną rolę urbanizacji i uprzemysłowienia w kształtowaniu nowego wymiaru takich zjawisk, jak „wzrost demograficzny, urbanizacja, powstanie rozbudowanej administracji i rozwój systemów oświatowych" ${ }^{11}$. Rozbudowa szkolnictwa oraz instytucji opiekuńczych i wychowawczych miała podstawowe znaczenie dla kształcenia, wychowania i socjalizacji młodego pokolenia. Droga do realnego ustanowienia powszechnego obowiązku szkolnego była długa. Przepisy ustanawiające przymus kształcenia dzieci wprowadzano na przestrzeni całego XIX wieku, między innymi w 1814 roku w Danii, w 1825 - w Prusach, w 1842 - w Szwecji, w 1848 w Norwegii, w 1867 - na terenie Austro-Węgier, w 1876 - w Wielkiej Brytanii, a w 1882 roku we Francji52. W Stanach Zjednoczonych proces wprowadzania obowiązkowej edukacji trwał od 1848 do 1918 roku. W odrodzonej Polsce obowiązkową bezpłatną szkołę powszechną dla wszystkich dzieci od 7. do 14. roku życia wprowadzono na mocy dekretu z 7 lutego 1919 roku. Oprócz szkolnictwa elementarnego, w drugiej połowie XIX i na początku XX wieku

47 T. Kizwalter, „Nowatorstwo i rutyny”. Społeczeństwo Królestwa Polskiego wobec procesów modernizacji (1840-1863), Warszawa 1991.

${ }^{48}$ M. Gloger, Pozytywizm: między nowoczesnościa a modernizmem, Pamiętnik Literacki, 2007, 1, s. 5-6.

${ }^{49}$ Z. Bauman, Wieloznaczność nowoczesna - nowoczesność wieloznaczna, przekł. J. Bauman, Warszawa 1995.

${ }^{50}$ J. Habermas, Filozoficzny dyskurs nowoczesności, przekł. M. Łukasiewicz, Kraków 2000, s. 16.

${ }^{51}$ T. Kizwalter, Ziemiaństwo połowy XIX w. wobec procesów modernizacji - idee kręgu Andrzeja Zamoyskiego, Przegląd Historyczny, 1987, 4, s. 656.

${ }_{52}$ J. Draus, R. Terlecki, Historia wychowania. Wiek XIX i XX, Kraków 2010, s. 23 i n. 
rozwijały się szkoły zawodowe i realne, oświata dorosłych, edukacja specjalna, wychowanie przedszkolne, instytucje opiekuńcze dla dzieci z ubogich środowisk, placówki resocjalizacyjne, organizacje społeczno-kulturalne, prowadzące również działalność oświatową.

Zgodnie z założeniami polityki edukacyjnej, szkoła miała być miejscem kształtowania poglądów i postaw szerokich rzesz ludzi. Rozbudowa państwowych i społecznych instytucji edukacyjnych zmieniła przeżywanie dzieciństwa i młodzieńczości, choć w odniesieniu do dzieci i młodzieży z niższych grup społecznych, pozostających poza systemem oświaty szkolnej albo uczęszczających tylko do szkół elementarnych, najbliższe środowiska społeczne (rodzina, grupa rówieśnicza, społeczność lokalna) nadal odgrywały znacznie większą rolę. Włodzimierz Mędrzecki analizując procesy socjalizacji polskiej młodzieży wiejskiej w okresie postyczniowego półwiecza i w okresie międzywojennym, podkreśla, że „rola czynników zewnętrznych wzrastała z pokolenia na pokolenie, nie na tyle jednak, aby zmienić ostatecznie przyjmowane postawy wobec świata i własnej grupy" ${ }^{\prime 53}$. Nie zmienia to faktu, że $\mathrm{w}$ dobie nowoczesności doświadczenia szkolne zaczęły odgrywać szczególnie istotną rolę w życiu dzieci i młodzieży. Analiza emocjonalnych oraz psychologicznych aspektów dzieciństwa i dorastania musi uwzględniać znaczenie szkoły jako miejsca kształtowania kompetencji, wiedzy, doświadczeń; warto przy tym wykorzystać wspomniane badania Rogoff, Correa-Ch'avez i Navichoc Cotuc. W odniesieniu do ziem polskich badania nad rolą szkolnictwa publicznego w okresie zaborów łączą się z pytaniem o (nie)skuteczność polityki władz zaborczych, mającej na celu pozbawienie młodego pokolenia poczucia rodzimej tożsamości narodowej oraz rolę inicjatyw oświatowych Polaków (a także zamieszkujących ziemie polskie Żydów, Ukraińców, Niemców i in.). Przed I wojną światową oraz w warunkach odbudowy własnej państwowości interesujące jest badanie procesu skolaryzacji w odniesieniu do dzieci z różnych grup społecznych, wyznaniowych i narodowościowych. Analizę modelu szkolnictwa, norm i zwyczajów szkolnych, treści i metod nauczania oraz „ukrytego programu” warto przeprowadzić z wykorzystaniem wiedzy z zakresu psychologii, co może pomóc w zrozumieniu szkolnych uwarunkowań psychicznego i społecznego funkcjonowania dzieci i adolescentów, budowania poczucia własnej wartości, kształtowania tożsamości.

Desygnatem nowoczesności był wzrost społecznego zainteresowania młodym pokoleniem, które przejawiał się między innymi w zakładaniu towarzystw mających na celu organizowanie opieki i wychowania dzieci oraz młodzieży ze środowisk najuboższych i zaniedbanych. Towarzystwa takie

${ }^{53}$ W. Mędrzecki, Młodzież wiejska na ziemiach Polski centralnej 1864-1939. Procesy socjalizacji, Warszawa 2002, s. 204. 
powstawały w całej Europie i USA (np. w 1874 r. założono New York Society for the Prevention of Cruelty to Children, w 1878 r. w Madrycie - La Sociedad Protectora de los Niňos, w 1884 r. w Londynie - The National Society for the Prevention of Cruelty to Children; w Królestwie Polskim od 1885 r. działało Towarzystwo Opieki nad Ubogimi Matkami i ich Dziećmi, a od 1906 r. - Towarzystwo Opieki nad Dziećmi) ${ }^{54}$. Odnosząc się do wpływu działalności tych organizacji oraz wszelkich instytucji dobroczynnych i samopomocowych na dobrostan dzieci i ich rodzin, warto byłoby podjąć próbę przeprowadzenia badań odwołujących się do ustaleń A. Huston, jakkolwiek interpretacji niepełnych danych z przełomu XIX i XX wieku należy oczywiście dokonywać z dużą ostrożnością.

Organizacje społeczne miały znaczący udział w zakładaniu różnego typu placówek opiekuńczo-wychowawczych, które zapewniając opiekę i wsparcie, stanowiły jednocześnie przejaw symptomatycznych dla epoki nowoczesnej tendencji do nadzorowania, kontrolowania, monitorowania zachowań dzieci i młodzieży z ubogich środowisk ${ }^{55}$. Dostrzegając pozytywne aspekty ich działalności, nietrudno zauważyć, że zamknięte placówki (domy dla sierot, zakłady resocjalizacyjne) nosiły atrybuty instytucji totalnych (w rozumieniu wprowadzonym przez Ervinga Goffmana), organizując całość życia swoich wychowanków i w dużym stopniu izolując ich od społeczeństwa. Dokonując interpretacji zachowań podopiecznych placówki „w kategoriach moralizujących w duchu jej formalnie przyjętych celów”, implikowano „pewne szersze założenia co do charakteru człowieka" ${ }^{56}$, co sprzyjało antycypowaniu i projektowaniu przyszłych losów wychowanków. Analizując działalność placówek dla dzieci i młodzieży pozbawionych właściwej opieki, warto wykorzystać koncepcje dotyczące stygmatyzacji i destygmatyzacji oraz psychologiczną wiedzę o strategiach radzenia sobie z piętnem.

Truizmem jest stwierdzenie, że biorąc pod uwagę wzrastający w epoce nowoczesnej udział wyspecjalizowanych instytucji, trzeba mieć na uwadze niezmiennie prymarną rolę rodziny w wychowaniu, edukacji i opiece nad dzieckiem. Badania z wykorzystaniem metod i pojęć z dziedziny psychologii nad wychowawczą i socjalizacyjną rolą rodziny w XIX i na początku XX wieku są niezwykle potrzebne, bowiem duża część studiów historycz-

54 A. Bołdyrew, Społeczeństwo Królestwa Polskiego wobec patologii społecznych w latach 18641914, Łódź 2016, s. 260.

${ }^{55} \mathrm{~W}$ realiach polskich $\mathrm{w}$ okresie zaborów widoczne były tendencje zbliżone - choć nie tożsame - do ujawniających się na Zachodzie, gdzie „nowocześni reformatorzy byli skoncentrowani na bezpieczeństwie i wydajności społeczeństwa, a obawy skierowane wobec młodych wyzwoliły zwiększoną kontrolę i interwencję państwa". H. Ostrowicka, Urządzanie młodzieży. Studium analityczno-krytyczne, Kraków 2015, s. 85.

56 E. Goffman, O pacjentach szpitali psychiatrycznych i mieszkańcach innych instytucji totalnych, przekł. O. Waśkiewicz, J. Łaszcz, Sopot 2011, s. 92. 
nych - także deklarujących podejście psychohistoryczne - $\mathrm{w}$ istocie odnosi się $\mathrm{w}$ niewielkim stopniu do psychologicznego wymiaru funkcjonowania rodziny i miejsca $\mathrm{w}$ niej dzieci ${ }^{57}$. Większą uwagę zwraca się na materialne warunki, obyczajowość, problemy higieniczne i zdrowotne, aspekty życia codziennego ${ }^{58}$. Istotne jest zatem badanie, $\mathrm{w}$ jakim stopniu rodziny zaspokajały biologiczne i psychologiczne potrzeby dziecka, kształtowały ich potrzeby poznawcze, emocjonalne i społeczne, jak odbywał się przekaz norm kulturowych i przygotowanie do wypełniania ról społecznych. Warte opisu są układy emocjonalnych odniesień, postawy rodzicielskie, klimat i style wychowania, dziecięce doświadczanie świata w rodzinnej mikrospołeczności. Analiza funkcjonowania rodzin, ich modeli i form alternatywnych, problemów życia rodzinnego $w$ realiach intensywnej modernizacji w wielokulturowych społeczeństwach wymaga podejścia interdyscyplinarnego. Wykorzystanie współczesnych teorii psychologicznych może pomóc w pogłębieniu rozumienia wielu zagadnień związanych z kondycją psychospołeczną rodziny, jej rolą w kształtowaniu osobowości i postaw dziecka, naturą związków emocjonalnych wewnątrz rodziny, komunikacją inter- oraz intrapersonalną i tym podobnych. Dla polskich realiów na początku XX wieku tego rodzaju badań, włączających perspektywę psychologiczną, nie prowadzono ${ }^{59}$. Tymczasem dostępne źródła, w tym egodokumenty (pamiętniki, dzienniki, autobiografie, życiorysy, listy), pozwalają na prowadzenie takich analiz. W pracy odnośnie tej kategorii źródeł warto także odnieść się do rudymentarnego w psychologii pojęcia ,ja”, określanego przez Bogdana Wojciszke jako

bardzo rozbudowana i chronicznie dostępna, choć luźno zorganizowana struktura różnych ról i tożsamości społecznych, przekonań na własny temat i samoocen oraz wartości i celów uznawanych za własne ${ }^{60}$.

Interesujące perspektywy, wykorzystujące podejście psychologiczne, rysują się przed badaniami rodzicielstwa oraz relacji międzypokoleniowych, $\mathrm{w}$ polskiej historiografii analizowanymi dotychczas z perspektywy historii społecznej, włączającej czasami także aspekty antropologiczno-kulturowe. Na przykład, badania przemian motywacji i postaw kobiet wobec macierzyństwa w świetle dokumentów osobistych, a także poradników i prasy warto połączyć

57 T. Pawelec, Dzieje i nieśrwiadomość, s. 250-251.

${ }^{58}$ Por. E. Jarosz, Dziecko i dzieciństwo - pejzaż wspótczesny. Rzecz o badaniach nad dzieciństwem, Pedagogika Społeczna, 2017, 2, s. 57-81.

${ }^{59}$ Na marginesie warto przypomnieć interesujące badania Renaty Doniec, która zastosowała teorię zasobów Stevana E. Hobfolla w odniesieniu do rodziny w Polsce w okresie socrealizmu. R. Doniec, Kondycja rodziny w czasach socjalizmu realnego - zasoby a możliwości rozwojowe, Edukacja Humanistyczna, 2017, 1, s. 11-31.

${ }^{60}$ B. Wojciszke, Psychologia społeczna, Warszawa 2013, s. 535. 
z analizą modelu opieki sprawowanej przez matkę nad niemowlęciem, stylu przywiązania oraz rozwoju małego dziecka. Pozwoliłoby to na opracowanie, uwzględniające podejście psychologiczne, „historii miłości macierzyńskiej”, alternatywne w zakresie metodologii wobec książki Elizabeth Badinter ${ }^{61}$.

\section{Zakończenie}

Włączenie perspektywy psychologicznej do analizy problematyki oświaty, wychowania oraz socjalizacji dzieci i młodzieży pozwala na podjęcie prób zrozumienia zjawisk i zachowań, które trudno zinterpretować lub które pozostają niezauważone w tradycyjnym badaniu historycznym. Może znacząco wzbogacić metodologię i praktykę historyczną, alternatywną w stosunku do pozytywistycznego modelu narracji historycznej, rozwijanego przez scjentystycznie nastawionych badaczy. W badaniach historyczno-pedagogicznych tego rodzaju inicjatywy podejmowano sporadycznie, znacznie częściej sięgając do wiedzy i aparatu pojęciowego z zakresu socjologii czy antropologii kulturowej. Włączenie teorii, sytuowanych w jednej z kilku najważniejszych perspektyw teoretycznych psychologii społecznej - poznawczej, teorii uczenia się, społeczno-kulturowej i motywacyjnej, może tworzyć interesujące możliwości „odczytania na nowo” źródeł historycznych, zwłaszcza różnego rodzaju źródeł narracyjnych, historiograficznych (opisowych) i epistolarnych; w szczególnym stopniu dotyczy to dokumentów osobistych. Zastosowanie wiedzy psychologicznej, szczególnie z zakresu psychologii rozwojowej i społecznej, w badaniach nad przeszłością edukacyjną wpisuje się w postulaty zwolenników tak zwanej społecznej koncepcji historii wychowania, podkreślających potrzebę poszukiwań epistemologicznych, pozwalających na jak najpełniejsze poznanie wieloaspektowej złożoności zjawisk społeczno-kulturowych i oświatowo-wychowawczych ${ }^{62}$. Integracja podejścia historycznego i psychologicznego rozszerza pole obserwacji procesów edukacji, wychowania i socjalizacji, wyznaczając zupełnie nową optykę badań nad dzieciństwem i dorastaniem w epoce nowoczesnej.

\section{BIBLIOGRAFIA}

Ariès Ph., Historia dzieciństwa. Dziecko i rodzina w dawnych czasach, przekł. M. Ochab, Wydawnictwo Marabut, Gdańsk 1995.

${ }^{61}$ E. Badinter, Historia miłości macierzyńskiej, przekł. K. Choiński, Warszawa 1998.

${ }^{62}$ D. Drynda, O koncepcjach historii wychowania - jako dyscypliny naukowej w Polsce II połowy XX wieku, [w:] Historia wychowania. Skrypt dla studentów pedagogiki, red. D. Drynda, Warszawa 2006, s. 19-20. 
Badinter E., Historia miłości macierzyńskiej, przekł. K. Choiński, Oficyna Wydawnicza Volumen, Warszawa 1998.

Bauman Z., Wieloznaczność nowoczesna - nowoczesność wieloznaczna, przekł. J. Bauman, Wydawnictwo Naukowe PWN, Warszawa 1995.

Bołdyrew A., Społeczeństwo Królestwa Polskiego wobec patologii społecznych w latach 18641914, Wydawnictwo Uniwersytetu Łódzkiego, Łódź 2016.

Browning Ch.R., Zwykli ludzie: 101. Policyjny Batalion Rezerwy i "ostateczne rozwiazanie" w Polsce, przekł. P. Budkiewicz, Dom Wydawniczy Bellona, Warszawa 2000.

Cioffi F., Freud i pseudonauka, przekł. R. Stachowski, Wydawnictwo WAM, Kraków 2010.

Crandall Ch.S., Ideologia i potoczne teorie piętna: usprawiedliwianie piętnowanie, [w:] Społeczna psychologia piętna, red. T.F. Heatherton, R.E. Kleck, M.R. Hebl, J.G. Hull, Wydawnictwo Naukowe PWN, Warszawa 2008.

de Mause L., Evolution of Childhood, [w:] The History of Childhood, red. L. de Mause, Jason Aronson, Northvale - London 1995.

Doliński D. i in., Would You Deliver an Electric Shock in 2015? Obedience in the Experimental Paradigm Developed by Stanley Milgram in the 50 Years Following the Original Studies, Social Psychological and Personality Science, 2018, 8.

Doniec R., Kondycja rodziny w czasach socjalizmu realnego - zasoby a możliwości rozwojowe, Edukacja Humanistyczna, 2017, 1.

Draus J., Terlecki R., Historia wychowania. Wiek XIX i XX, Wydawnictwo WAM, Kraków 2010.

Drynda D., O koncepcjach historii wychowania - jako dyscypliny naukowej w Polsce II połowy XX wieku, [w:] Historia wychowania. Skrypt dla studentów pedagogiki, red. D. Drynda, Wydawnictwo Wyższej Szkoły Pedagogicznej TWP, Warszawa 2006.

Dymkowski M., O źródłach Holokaustu w świetle badań nad destrukcyjnym postuszeństwem, HISTORYKA. Studia Metodologiczne, 2017, 47.

Elovitz P.H., The Making of Psychohistory: Origins, Controversies, and Pioneering Contributors, Routledge, New York 2018.

Ende A., Dzieciństwo psychohistoryka oraz historia dziecinstwa, [w:] Psyche i Klio: historia w oczach psychohistoryków, oprac. T. Pawelec, Wydawnictwo UMCS, Lublin 2002.

Eysenck H.J., Zmierzch i upadek imperium Freuda, przekł. A. Jarczyk, Wydawnictwo WiR, Kraków 2002.

Gloger M., Pozytywizm: między nowoczesnościa a modernizmem, Pamiętnik Literacki, 2007, 1.

Goffman E., O pacjentach szpitali psychiatrycznych i mieszkańcach innych instytucji totalnych, przekł. O. Waśkiewicz, J. Łaszcz, Gdańskie Wydawnictwo Psychologiczne, Sopot 2011.

Habermas J., Filozoficzny dyskurs nowoczesności, przekł. M. Łukasiewicz, Wydawnictwo Universitas, Kraków 2000.

Huston A.C., The Effects of Welfare Reform and Poverty Policies on Children and Families, [w:] Developmental Psychology and Social Change: Research, History and Policy, red. D.B. Pillemer, S.H. White, Cambridge University Press, New York 2005.

Jarosz E., Dziecko i dzieciństwo - pejzaż wspótczesny. Rzecz o badaniach nad dzieciństwem, Pedagogika Społeczna, 2017, 2.

Kizwalter T., Ziemiaństwo połowy XIX w. wobec procesów modernizacji - idee kręgu Andrzeja Zamoyskiego, Przegląd Historyczny, 1987, 4.

Kizwalter T., „Nowatorstwo i rutyny”. Społeczeństwo Królestwa Polskiego wobec procesów modernizacji (1840-1863), Państwowe Wydawnictwo Naukowe, Warszawa 1991.

Kurth W., Wechselseitige Bezüge von Bindungstheorie und psychohistorischer Forschung, Jahrbuch für Psychohistorische Forschung, 2001, 2. 
Kurth W., Die psychogene Theorie von Lloyd deMause - Plädoyer für eine konstruktive Weiterentwicklung, Jahrbuch für Psychohistorische Forschung, 2009, 10.

Leichtman M.D., Wang Q., A Socio-historical Perspective on Autobiographical Memory Development, [w:] Developmental Psychology and Social Change: Research, History and Policy, red. D.B. Pillemer, S.H. White, Cambridge University Press, New York 2005.

McKinley Runyan W., From the Study of Lives and Psychohistory to Historicizing Psychology: A Conceptual Journey, Annual of Psychoanalysis, 2003, XXXI: Psychoanalysis and History.

McKinley Runyan W., Reconceptualizing the Relationships between History and Psychology, [w:] Psychology and Historical Interpretation, red. W. McKinley Runyan, Oxford University Press, New York 1988.

Mędrzecki W., Młodzież wiejska na ziemiach Polski centralnej 1864-1939. Procesy socjalizacji, Wydawnictwo DiG, Warszawa 2002.

Milgram S., Behavioral Study of Obedience, Journal of Abnormal and Social Psychology, $1963,67$.

Miller C.R., Major B., Radzenie sobie z piętnem i uprzedzeniem, [w:] Społeczna psychologia piętna, red. T.F. Heatherton, R.E. Kleck, M.R. Hebl, J.G. Hull, Wydawnictwo Naukowe PWN, Warszawa 2008.

Open Science Collaboration [B. Nosek i in.], Estimating the reproducibility of psychological science, Science, 2015, 349.

Ostrowicka H., Urządzanie młodzieży. Studium analityczno-krytyczne, Oficyna Wydawnicza Impuls, Kraków 2015.

Pawelec T., Psychohistoria jako paradygmat badań historycznych. Konceptualizacja i program badawczy, Kultura i Historia, 2001, 1.

Pawelec T., Dzieje i nieświadomość: założenia teoretyczne i praktyka badawcza psychohistorii, Wydawnictwo Uniwersytetu Śląskiego, Katowice 2004.

Pillemer D.B., White S.H., Introduction: What Kind of Science is Developmental Psychology?, [w:] Developmental Psychology and Social Change: Research, History and Policy, red. D.B. Pillemer, S.H. White, Cambridge University Press, New York 2005.

Plamper J., The History of Emotions, Oxford University Press, Oxford 2017.

Popper K., Science: Conjectures and Refutations, [w:] Philosophy of Science and the Occult, red. P. Grim, State University of New York Press, Albany 1990.

Psyche i Klio: historia w oczach psychohistoryków, oprac. T. Pawelec, Wydawnictwo UMCS, Lublin 2002.

Rogoff B., Correa-Ch'avez M., Navichoc Cotuc M., A Cultural/Historical View of Schooling in Human Development, [w:] Developmental Psychology and Social Change: Research, History and Policy, red. D.B. Pillemer, S.H. White, Cambridge University Press, New York 2005.

Strozier Ch.B., Interview, [w:] The Best of the Journal "Clio's Psyche” (1994-2005), red. P.H. Elovitz, Psychohistory Forum, Franklin Lakes 2013.

Sztompka P., Socjologia zmian społecznych, przekł. J. Konieczny, Wydawnictwo Znak, Kraków 2005.

Tileagă C., Byford J., Introduction: psychology and history - themes, debates, overlaps and borrowings, [w:] Psychology and History: Interdisciplinary Explorations, red. C. Tileagă, J. Byford, Cambridge University Press, New York 2014.

Waloszek A., Amerykańska historiografia poświęcona dzieciom i dziecinstwu w Stanach Zjednoczonych od czasów kolonialnych do wielkiego kryzysu ekonomicznego, Kwartalnik Historyczny, 1993, 2.

Wojciszke B., Psychologia społeczna, Wydawnictwo Naukowe Scholar, Warszawa 2013. 